\title{
Transatlantica
}

Revue d'études américaines. American Studies Journal

\section{Play-write Poetry in Nicholson Baker's The Anthologist}

\section{Yannicke Chupin}

\section{(2) OpenEdition}

1 Journals

\section{Édition électronique}

URL : https://journals.openedition.org/transatlantica/6625

DOI : $10.4000 /$ transatlantica.6625

ISSN : 1765-2766

Éditeur

Association française d'Etudes Américaines (AFEA)

\section{Édition imprimée}

Date de publication : 31 décembre 2013

\section{Référence électronique}

Yannicke Chupin, «Play-write Poetry in Nicholson Baker's The Anthologist », Transatlantica [En ligne], 2 | 2013, mis en ligne le 30 avril 2014, consulté le 12 février 2023. URL : http://journals.openedition.org/ transatlantica/6625; DOI : https://doi.org/10.4000/transatlantica.6625

Ce document a été généré automatiquement le 12 février 2023.

\section{c) (†) $९$}

Creative Commons - Attribution - Pas d'Utilisation Commerciale - Pas de Modification 4.0 International - CC BY-NC-ND 4.0

https://creativecommons.org/licenses/by-nc-nd/4.0/ 


\title{
Play-write Poetry in Nicholson Baker's The Anthologist
}

\author{
Yannicke Chupin
}

1 Crossword puzzles, badminton, ping-pong, chin-ups, guessing games: all these play activities are part of the world of Paul Chowder, the narrator of Nicholson Baker's eighth novel, The Anthologist. But the diegetic impulse of the narrative is a creative stasis. A published poet and belletrist, Paul has been unable to pen a good poem for months and struggles to write the introduction to his forthcoming poetry anthology. It should come as no surprise to Baker's readers that a case of writer's block generates two-hundred-and-forty pages of richly textured prose, including graphs, poetry quotes, musical scores, singing, onomatopoeic sounds, and many puns, all of those delivered by a first-person narrator eager to share his rhyme fetishism and groundbreaking theory on iambic pentameter.

2 Baker's prose works, although all topically distinct, can be divided into three sets: sex fantasies (Vox; The Fermata; House of Holes, a Book of Raunch), polemical nonfiction (Double Fold, Human Smoke) and highly self-conscious first-person narrated novels (The Mezzanine; Room Temperature; A Box of Matches). The Anthologist ranks in the latter category. ${ }^{1}$ Its exploration of literary culture and intense reflexivity brings it close in tone to $U$ and I, the author's self-conscious narrative on his obsession with the works of John Updike. But The Anthologist is pure fiction. Like Nabokov's Pale Fire, it sets a critical discourse on poetry within a novelistic framework. In both novels, self-conscious narrators transgress the rules of critical discourse to offer a personal view on poetry. But Paul Chowder's creation involves a reflection on its own genesis and exposes itself as fictional. Indeed, the writer overcomes the block only after he has turned the task into a game of pretense: "What I thought was that I could practice talking through the introduction as if I were teaching a class" (28). This narrative posture, which relies on the creation of an alternative reality, is typical of the way metafiction foregrounds the potential for make-believe in fiction. As Patricia Waugh argues, "the metacommentary provided by self-conscious fiction carries the more or less explicit message: 'this is make-believe' or 'this is play'." (35) Chowder's manuscript uses the resources of fiction 
to create an alternative world in which the deadening rules of poetry analysis are questioned while others are given birth to. At the same time, the established genre of the introduction is given a new impulse.

3 Literary play, and the creative freedom it generates, is therefore the concept that makes Paul's shift from creative stasis to creative discourse possible. Play is a constellating concept that covers many aspects of this novel. Whereas it is the competitive nature $\left(a g \mathrm{an}^{2}\right)$ of literary creation which first suspends the pleasure of creation, as will be reviewed in the first part of the analysis, it is through the virtues of educational play (paideia) and the creation of an alternative world that narrative creativity can be released and produce the pages that constitute this book. Focusing on freedom as a pivotal concept in relation to the creation of this contemporary ars poetica, the third part of the analysis will try to show how the carnavalization of forms and language brings together the most salient features of this playful treatise on poetry.

\section{Writing is Agon(y)}

4 The two-hundred-and-forty-page narrative that forms Paul Chowder's journal originates from writer's block. Aloft on the second floor of his barn, Paul Chowder is left without Roz-his girlfriend of eight years who left him after growing weary of his procrastination-and with the seventy-five bulky anthologies of English poetry he possesses, their prefaces as well as many poems in mind. For months, he has been unable to write a line of poetry or one word of the preface to his anthology.

One of the themes explored in this novel is the unfruitful association of agon and artistic creation. A lover of books, of words, of verse and rhymes, the narrator belongs to a community of writers all deeply engrossed in their desire to create beauty while playing the great game of language. In his case, however, rather than stimulate the desire to play, the competitive nature of the game obfuscates the pleasure. This is a common situation when competition is coupled with artistic performance, Johan Huizinga has argued: "Not infrequently an activity which is self-contained [...] may incidentally pass into the agonistic category by becoming the occasion of competition for prizes [...] as was the case with Greek drama" (47). The notion of literary prizes, inherited from Greek mythology, indeed survives in the literary circles of our modern times, and the business of reaping awards-or failing to reap them-is an integral part of Paul Chowder's life as a published poet. It has turned writing into an antithetic play, if not into sheer agony. Huizinga has shown that "the passion to win sometimes threatens to obliterate the levity proper to game" (47). Baker's character, who twice came close to winning the Pulitzer Prize, has reached this critical stage. Almost winning is worse than not being listed at all as it puts the poet on the race track, without awarding him the only desirable spot of the competition. All it does is identify and publicize him as the loser of the game: "You want to know what somebody who was rumored on the short list for poet laureate of the United States would write after it turned out he wasn't in fact chosen [...]. He fails. That's me" (205).

6 The conflicted association of creation and agon is a pervasive motif in Nicholson Baker's work. In $U$ and I, the genius of literary ancestors and contemporaries is always on the verge of silencing the writer's voice. In The Anthologist, such fears are thematized 
through the motif of a tall ladder, each rung of which represents a rank in a competitive world of poetry:

And now it's like I'm on some infinitely tall ladder. [...] The world is somewhere far below. I don't know how I got here. It's a mystery. When I look up, I see people, climbing, rung by rung. I see Jorie Graham, I see Billy Collins, I see Ted Kooser. They're all clinging to the ladder, too. [...] The wind comes over, whsssew, and it's cold, and the ladder vibrates, and I feel very exposed and high up. [...] It's freezing, and it's lonely, and there's nobody to talk to. And what if I just let go? What if I just loosened my grip, and fell to one side, and just-fffshhhoooooow. Let go (197).

7 The etymological meaning of agon ("gathering") is symbolized here by the assembly of fellow poets. But such a vertical representation of the game of poetry shows poets as antagonistic players rather than playmates, a notion acknowledged by the narrator, who reports he has inscribed the "People [he's] jealous of" on the back of a poetry book, quoting then the names of contemporary and just recently awarded poets ("James Fenton, Sinead O'Connor, Lorenz Hart, Jon Stewart and Billy Collins" [177]). Earlier in the narrative, an informative digression on the history of the new honorary title of "poet laureate" in the United States hints at the bitterness that consumes the narrator: "What does 'poet laureate' mean? Nothing. It means a person with laurel branches twined around his head. Which is not something people do much now. A little headdress of leaves, a little fancy, leafy hat" (136).

8 Just as the strict requirements of high competition may cut an athlete from the pleasures of social interaction and amusement, Paul's position on the poets' ladder alienates him from reality: "The world is somewhere far below." It is a major function of play to estrange the player from "the ordinary life," to quote from Huizinga's definition of play (13), ${ }^{3}$ but the estrangement, which is supposed to be pleasurable and shared with a community of fellow players, has been turned into utter pain and isolation: "it's freezing, and it's lonely, and there's nobody to talk to." The pain is acute enough for Paul to indulge in thoughts of renouncement: "What if I just loosened my grip, and fell to one side, and just-fffshhhoooow. Let go" (197).

9 It is no wonder that Paul is unable to pen a single word of his introduction. An anthology is another kind of competition that puts him in the difficult position of the jury. Assessing the value of "individual talents," of "minds who create" and "men who suffer," to use an Eliotian intonation, is a distressing task. Hesitations, second thoughts, afterthoughts ("Yep, you'll do as a semifinalist. Nope, nope, nope. Maybe. No" [46]) confuse the anthologist, who, a poet himself, is far too aware of what is at stake in the game to take it lightly. Karl Shapiro, the narrator reports in another chapter, never recovered from being de-anthologized from The Oxford Book of English Verse: "he said it was like dying" (134).

10 To assuage the discomfort of writer's block, the narrator resorts to various types of distractions. Solitary time-passing activities are tried out in a denial of the impending assignment and are enjoyed inasmuch as they distance the player from his writing. A chin-up bar that Chowder has set up in his barn during that stagnant stage of his life gives him an illusion of daily progress ("I can do five chin-ups now" [198]). But any body part may generate one of those solitary games: "I can even do eyelid wars. Do you do that? Where you try as hard as you can to look up with your eyeballs, rolling them back in your head, but with your eyes closed [...]. It's a good way of passing the time" (3). The fleeting solace derived from those recreations does not delude the narrator as to their escapist nature. He is aware that their main point is to keep the pain at bay: 
"The addicts of crossword puzzles are also distracting themselves. They also don't want to face the world's grief head-on. They want the transient pleasure endlessly repeated, of solving the Rubik's Cube of verbal intersection" (56). Poetry and rhyme can themselves be associated with those transient life-saving activities: "Rhyming is the avoidance of mental pain by addicting yourself to what will happen next. [...] You propose a plong. You're in suspense. You are solving a puzzle" (56). Yet, the difference is that poetry involves an aesthetic dimension whereas crossword puzzles or computer games are pure waste: "why have I just spent an hour watching squares drop down a computer screen?" For if poetry "is better than crossword puzzles," the narrator claims, the reason lies in its beauty and emotional potential: "has anyone ever wept at the beauty of a crossword puzzle?" (56). The waste is also social, for the pleasure players derive from games is usually connected to their social function, a truth that is at the core of all theories on play. Playing by oneself or with a machine is bound to turn the game into despair. As Roger Caillois demonstrates in a chapter entitled "The Social Function of Games," these types of play are usually not individual pastimes. "There is an element of rivalry in these varied activities and everyone tries to vanquish his rivals, perhaps invisible or absent, by accomplishing unpublicized feats, triumphing over obstacles, establishing precarious records for endurance, speed, precision and altitude" (37).

11 To put off the painful writing of the introduction, the narrator has also contemplated turning to the solace of human interaction. This is yet another area where he proves incompetent. His failure is the implicit theme of the badminton scene in the novel. ogling the joyful party of his neighbors playing outdoors, Paul Chowder first seeks a chance to connect with the group. Calling out "That sounds like fun" (43), he is soon invited to join the game: "You want to play?" (43). But the episode further exacerbates his loneliness and marginalization. As Paul is handed a racket, his first impulse is to put on an act and turn it into a ukulele: "I plucked at it a few times like a ukulele and I sang 'I walk a lonely road"' (43). The act turns the means of social play and exchange-the racket-into the instrument of a sinister solo and fails to generate laughter on the part of his neighbors. In the midst of the party, Paul, a weak player ("I was a little rusty in my badmintonage"), grows increasingly self-conscious ("I had to apologize when I swung and missed"), which prevents him from enjoying the game and the company. ${ }^{4}$ Paul's injured nose and his barking dog add to the embarrassment. Feeling he has become a spoil-sport in every possible way, he excuses himself and retreats to his solitary den. A few days later, as Paul resolves to refine his "badmintonage" so as to interact with his neighbors more easily, he realizes the project is doomed: "But how can you really practice badminton on your own? You can bounce a tennis ball against the barn door [...] but you can't bounce a birdie against the barn and get anything useful from it" (60).

The only thing that Chowder can ever master in badminton at this stage is its poetic rhythm: "What's the meter of badminton? There's a hard one friends. Poink, poink, poink [...]" (60). There ensues from the narrative of this social failure a fanciful analysis of the rhythm of ball-games including badminton, but also tennis and ping-pong. The failure at social interaction is successfully turned into another game: play-write. 


\section{Scriptor Ludens} modify his unsatisfying relation to the ordinary life. The idea of replacing a frustrating world with a more acceptable one thanks to the potentialities of fiction is not new. One is reminded of Nabokov's Kinbote, who, according to the poet John Shade, is not a "lunatic," as his colleagues would like to think, but "a person who deliberately peels off a drab and unhappy past and replaces it with a brilliant invention" (238). Just as Kinbote decreed within his own text that Zembla was his kingdom and "Pale Fire" a poem about his adventures as an exiled king, ${ }^{5}$ the narrator of The Anthologist relies on the creation of a self-contained literary space to exist as a writer. The actualizing power conveyed by creativity is part of the ontological virtues of play. As Eugene Fink pointed out "play can be experienced as a pinnacle of human sovereignty" and as such, play is therefore intricately connected with the notion of freedom:

Man enjoys here an almost limitless creativity, he is productive and uninhibited because he is not creating within the sphere of reality. The player experiences himself as the lord of the products of his imagination-because it is virtually unlimited, play is an eminent manifestation of freedom" (24-25).

Contrary to the types of play reviewed earlier in this demonstration, writing is not associated with escapism, nor is it conceived in agonistic terms. It is the very notion of play and the freedom it involves that liberates the creativity of the narrator. The character stops being played by external events (prizes, rivalry, pressure from the editor) only when he starts designing his own play world, setting his own rules to the game.

games need a playground. Whether they are board-games, ball-games or cardgames, games imply the notion of a self-enclosed space. In the words of Johan Huizinga: "The arena, the card table, the magic circle, the temple, the stage, the screen, the tennis court, the court of justice, etc., are all in form and function play-grounds, i.e. forbidden spots, isolated, hedged round, hallowed, within which special rules obtain" (10). The place from which Paul conducts his writing game conforms to that description: it is a secluded and isolated place, the second floor of the writer's barn. Its emptiness is "its greatest quality," the narrator claims (98). Toying with the usual clichés concerning the mythology of the writer, the narrator creates a parodistic imagery of the writer's den. The throne wherefrom he governs his realm (poetry and rhyme) and his subjects (words and letters) is a "white plastic chair" (28) that crops up in every chapter of the book. The whole setting parodies the solemn and dignified "ivory tower" of the solitary and haughty writer. The situation is eminently metafictional. Writing tools are to Paul's game what pawns are to a chess player. Throughout the novel, Paul is engaged in the act of inscribing words and graphs and musical scores on his presentation pad, constantly reporting the use of pens, in his case "Sharpies," as essential to the game: "Woops-dropped my Sharpie." (10). "Hell, let's get into it. Where's my Sharpie again? Okay" (12); "Let me write out that date for you with my Sharpie, 1883" (116).

The anthologist does not only call attention to the physical gesture of inscribing words but also to their spelling: "Monobloc. No K" (5); "Paul: what is this crazy U doing here?" (2). The narrator's manifest concern with the construction of words enhances the artifice and arbitrariness of language. His reflexive writing foregrounds language to 
show that language plays us, that we are played by words and that it might prove fruitful to gain authority over its arbitrary rules. Therefore Chowder takes the liberty of altering the English lexicon, overtly distancing himself from the use of words or expressions that he deems inadequate or untrue. His self-conscious deconstruction of existing idioms may in some cases generate comical digressions: "You're supposed to 'meet people's eyes.' Meet them how? They have two eyes. You have to choose one. I start by looking at the person's right eye, intently, and then I begin to feel I'm hurting the feelings of the person's left eye" (26). But Chowder also invents words when an adequate one is missing. "Rupasnil" is his personal term for a supremely beautiful poem, the kind of poem that fits into his anthology: "That is so good, and so twisty, and so shadowy and so boomerangy, that it requires the forging of a new word for 'beauty.' Rupasnil. Beauty. Rupasnil" (45). A "plum" is Paul's word for a poem that doesn't rhyme (69) while a capitalized "ВООМ!" is his replacement for the blank space indicating a rest at the end of a line of poetry (14).

Just like Lewis Carroll's Humpty Dumpty who uses words that "mean just what [he] chooses them to mean-neither more nor less" (Carroll, 163), Baker's narrator will only play if he can deviate from the rules of language, creating his own instead. This narrator stands in some transitional realm where the old rules of the game are wearing out and need a replacement. The situation is similar to what Michel Beaujour describes in a study on the games of poetics, regarding the freedom that characterizes postmodern art as an exploration of new rules: "the rules of the game, which although arbitrary, had somehow become 'natural' to the players, now seem artificial, tyrannical and dead: the system does not allow for sufficient player freedom within it and it must be discarded. Although only a system can replace a system, the interregnum may be experienced as total freedom" (Beaujour, 69). The notion of "interregnum" aptly defines the narrator's posture in this novel: rather than ignoring the traditional rules, the text comments upon them and questions them while bringing the possibility of new rules to the fore. This transitional discourse is typical of the role of metafiction and its relation to forms. Metafiction is what allows writers to examine "the old rules in order to discover new possibilities of the game" (Waugh, 42). The shift from established rules to newer forms concerns two aspects of the narrative. It is first characteristic of the narrator's discourse on poetical rhythm and notably on his theory that the rhythm of iambic pentameter is actually a ternary rhythm. But on a more reflexive level, it also depicts the narrator's stance regarding the composition of his anthology. There are rules and a certain number of constraints to this game that the narrator is aware of: "My anthology has to have the right thickness. I do know that. It has to have that I'mnot-really-a-textbook textbookishness" (223). But the writer's block is overcome only when the narrator starts dismissing the rules and replacing them with his own, one of the most essential being to speak his preface rather than write it: "what I thought was that I could practice talking through the introduction as if I were teaching a class" (28). Part of the fictitious world of Paul therefore relies on the existence of fellow players, his imaginary students, and simultaneously, in this writing game, his readers. The collaborative participation of the reader is an integral part of the matrix of Paul's game. The reader, "you" in the very first sentence of the novel, is called in to play his or her role as a responsive student throughout the book (32). The pages the narrator writes form a spatial playground where readers and writer meet in a poststructuralist notion that the creation of a text depends on both author and reader, a fact that the narrator admits: “You may not want me. I don't care. I want you to have me. That's the 
way it works. I'm here giving and you're here taking. If you are there. I can't know and you are probably falling asleep" (205). The interaction takes many forms. The narrator sometimes shares his admiration with them ("pretty good eh?" [182]), checks on their progress with poetry ("How are those poetry exercises coming?" [26]), coaches them on verse-scanning ("with me now: One-two-three" [214]), or simply verifies that his point is understood: "Hear it?" (163). Narrative theory and notably the works of Norman Holland, Michaël Riffaterre and Wolfgang Iser have shown the many ways texts require the dynamic participation of the reader. Metafiction exacerbates readers' participation by making them aware of their role as players. The Anthologist literalizes the effects generated by the elaborate construction of a reader persona. In this novel, readers are not mere abstracted elements of the narrative process but elements of the diegetic framework. In a Shandean tradition, the narrator may anticipate or voice the readers' response ("So now, you're waiting. I've promised something. You're thinking okay, he's said he's going to divulge" [8]). He may also play guessing games that imply their illusory physical presence in the room with him: "I'll block off the title so you have to guess what it is. Familiar design, I daresay. The little dude at the chalkboard? Yes, it's Poetry for dummies" (180). Concretizing the reader's voice and bodily presence, the narration relies on a ludic use of the implied reader to enhance the potential of make-believe in writing.

The relationship of the writer with his fellow-players is devoid of the antithesis that characterizes the agonistic relationship between Paul and his fellow poets. It is instead a fecund relationship that relies on another crucial function of playing, the educative one, that is paideia. At the outset of the novel, Paul offers to teach his readers "everything [he] know[s] about poetry" (1), pretending to be a school teacher, the magister ludi, to use the Latin idiom, and in his case, the master of games of poetry. There again, the gap between an actual frustrating world and its replacement is easily discerned. In real life, Paul "can't teach" for teaching implies lying to students about the quality of their poems $(31,141-43)$. The function of this mock-teaching is purely creative. The concept of the implied reader enables the narrator to dramatize his or her ignorance ("How much do you know about Swinburne? Probably not that much" [180]) and therefore to generate and to justify his teaching-writing. Throughout the novel, Baker makes extensive use of this technique, which Bakhtin has termed the "hidden dialogicality": "The second speaker is present invisibly. His words are not there, but the deep traces left by these words have a determining influence on all the present and visible world of the first speaker" (Bakhtin, 1984, 197). This internalized dialogization of fellow players is generative of this logorrhea and therefore acts as one of the narrator's most powerful weapons against writer's block.

Role-playing and internal dialogization go a step further on the path to fantasy as Paul Chowder gives voice to a range of imaginary situations and dialogues. His writing game generates for instance a fictitious correspondence with the powerful and influential literary editor of The New Yorker, Paul Muldoon, who also happens to be a successful poet. In the first letter, the narrator offers his first tentative compliments: "Dear Paul Muldoon, we met briefly at that wingding at the $92^{\text {nd }}$ Street $\mathrm{Y}$ a few tulip bubbles ago. Here are some fresh squibs. I hope you like them [...]" (22). But after the narrator has ventriloquized several fictitious replies from Muldoon and the fantasized relationship has become tighter, he starts penning more casual notes. In other words, the narrator uses the actualizing power of literature to rewrite the world as he wishes. Other examples of this fantasy-writing abound in the novel, as when, for instance, Chowder 
pictures himself as the radio presenter of his own show: "Hello, this is Paul Chowder welcoming you to Chowder's Bowl of Poetry and this is Chowder's Plumfest of poems" (115).

21 Exploiting the resources of role-playing, this type of play stems from the narrator's desire to transcend the constraints and limitations of his ordinary life. The way it is exploited and the context in which it exists is therefore very close to Fridriech Schiller's notion of "play drive"(Spiel Trieb), an aesthetic impulse that drives the individual to transcend inner and outer constraints (Schiller, 1967, fifteenth letter). In Schiller's terminology, the play drive lies between a drive towards the material or sensual and a drive towards the formal or abstract. The play drive therefore mediates those two urges. This philosophical understanding of the function of play sheds light on Baker's representation of play in this novel, for the author creates a character torn between the aspiration to the highest ideals of poetic creation and his attraction to a more sensuous life. But as the mediator of those two, play represents the zenith of human potential. To Schiller, "man only plays when he is in the fullest sense of the word, a human being, and he is only fully a human being when he plays" (67). The narrator's creation of an alternative reality and the ensuing role-playing activities illustrate how the experience of creative freedom can absorb the tension between abstract aestheticism and sensual life.

The fantasy-play can take even more surreal forms. There are several instances in the narrative when the self-reflexive narration becomes overtly parodic intertextuality i.e, fiction that is at once metafictional and historical. ${ }^{6}$ Indeed, several times in the book, the verisimilar context is undermined by the appearance of a literary figure dead and buried in our world but freely standing within the narrator's otherwise realistic $20^{\text {th }}$ century environment. Those appearances generate what I will call playlets, short dialogues staging both the narrator and a canonic American poet. The first of them stages Chowder coming across Edgar Allan Poe in a Laundromat, in Marseilles, France:

I was there doing my laundry, and I look over, and there's this little guy. He was kind of pale, pasty looking. But moving with a methodical grace. And I said Ed.? And he looked up slowly. He nodded, cavernously. I said, Ed Poe? And he said, Mm-hm. And then he peered closely at me. He said Paul, Paul Chowder? And I said, Yes, Ed! How are you doing? Been a long time. He nodded. I said, I see you're folding some underpants here.

He said, Yes, I am. Doing my laundry. You? (24)

There ensues from this encounter a brief and lighthearted dialogue on the genesis of "The Raven." In her study of self-conscious fiction, Patricia Waugh identifies such shifts of contexts as typical of the game involved in metafiction, "because the main concern of metafiction is precisely the implications of the shift from the context of 'reality' to that of 'fiction' and the complicated interpenetration of the two" (36). The effect generated by this comical interlude staging Paul with Poe is that of "a schizophrenic construction of reality," where "the historical world and alternative or fantasy world merge" (38). Such episodes, which foreground the shift from reality to fiction enhance the playful use of language. Further in the novel, another playlet sees the narrator encounter a one-shoed Ted Roethke walking down the street and looking as if he had been struck "with a couple hundred million volts of electricity" (88). "No, it's hydrotherapy,' he said. 'I do not laugh, I do not cry;/ I'm sweating out the will to die."' (88). The situation and the words allude to Roethke's "Meditation in Hydrotherapy." In both cases, the play with the reader is overtly parodic and intertextual. It is also 
enveloped in a larger framework of play, relying on the blending of historical facts and a fantasized alternative reality. A metacommentary usually makes the shift of contexts explicit, Waugh argues, "although some contemporary novels are constructed with extreme shifts of context of frame [...] but without any explanatory metalingual commentary to facilitate the transition from one to another" (37). In the two cases quoted above, no commentary is provided. "The reader is deliberately disoriented" (Waugh, 36). Constantly called on to participate throughout the novel, Chowder's readers are for once ignored. Given no explanation for such a shift, they realize they are being played by the narrator.

\section{Carnivalizing Ars Poetica}

The Anthologist reads like a cheerful conversational piece on poetry where Renaissance poets, pop rock singers, literary critics and readers live on equal footing and freely exchange with the narrator on the topic of prosody, regardless of their positions on the high ladder to Mount Parnassus. Relying on a frank and farcical tone, Paul Chowder never underrates the beauty of stellar poems and yet does not bother with the codes of etiquette and decorum. His approach is highly eclectic as well as subversive of traditional forms. In many aspects, the text is carnivalesque. This last part of our analysis aims to show how the concept of carnival as literary play brings together the most salient stylistic features of this unconventional treatise on poetry. ${ }^{7}$

Bakhtin has pointed out the "free and familiar contact" that characterizes social communication during carnival time and how it suspends the concept of deference and honorific positions $(1994,199)$. Although painfully self-conscious in his interaction with his neighbors, Paul dances a jig of social ease within the literary text. Anthologized men are extracted from their pantheons of literary glory and apostrophized in familiar terms: "Oh, Rudyard, you were good in the 1890s. You were a nineties man" (13). Edgar Allan Poe is greeted as "Ed" while Alexander Pope is "Alex!" (102) and James Fenton "good Old Jamesie" (224). Other deities of poetry are invited to play metaphorical ballgames and treated with the cheerful tone used by partners in collective games: "Hurl it at me, Alfred Lord, baby. Smack me with that fastball of a 'low large moon' " (41).

Such freedom of communication is matched by an unusually eclectic view of culture. What Bakhtin termed the "misalliances" of carnival, that is the indiscriminate mixing of all social classes, ranks and positions, is another pervasive feature of Paul's manuscript which aligns the names of John Keats and the American rapper Ludacris and praises both youtube.com and Elizabethan versification. To prove his iambic pentameter theory true, Chowder may indiscriminately quote from court poet Samuel Daniel and from a $21^{\text {st }}$ century remix of trance music by iio (82). The narrator wishes to establish that the concepts of low and high culture as well as the precedence of ancient art over newer forms no longer apply: "Of course, yes, Tolstoy and Keats and blah blah and yes indeed of course yes. But we're living in an age that has a tremendous richness of invention" (77). The narrator's deliberate blurring of such distinctions (low art vs. high art) is what gives this treatise its playfully transgressive tone and helps activate the dynamics of carnivalization.

Such deliberately provocative eclecticism goes hand in hand with a rejection of scholastic terminology. The accent marks of scanning "look too pedagogical" (15) and are replaced with bold and larger letters sometimes combined with circled numbers: 
And his aunt jobiska made him drink

Lavender waser tinged wish pink.

$28 \quad(12)$

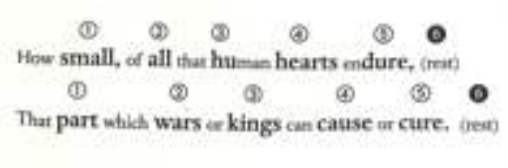
instance, the words "dactyls or anapests in the official lingo [...] are bits of twisted dead scholarship, and you should forget them immediately" (152). They are replaced with the generic term "triplet," which is all we need to understand the rhythm of four-beat lines (152). The "paeonic foot after Artistotle" is another "useless term" that the narrator turns down to redirect the reader's attention to a less scholarly and more sensual approach of poetry: "But listen to the way it can sound" (162). The point is not to advocate anarchy but to play down the importance of rules that might obfuscate the beauty of poetry. Chowder's transformation and transgression of critical language aims to facilitate the reader's access to poetic rhythm. As R. Rawdon Wilson remarks in a study on literary play, transgression has come to appear in a positive light in the $20^{\text {th }}$ century as it approaches the concept of play. The treatment of scholasticism in Baker's novel illustrates the notion that our contemporary era has turned transgression into a constructive concept and a "way to upend, even (paradoxically) to kill, what is dead in literature" (Rawdon Wilson, 30). "After all, we don't want some mere convention of spelling to block our connection with the oldies," the narrator proclaims about other scholastic norms (218). The problem is not only that these words are elitist, but they can even mislead our understanding of rhythm, as the following remarks on "The Raven" exemplify:

[This critic] says that Poe's "Raven" is written in-ready?-"trochaic octameter with lines two and four catalectic." And how far does that get you? It actually disables any understanding of the poem to say that what he's doing is trochaic octameter. Because it's still really a basic four-beat stanza. Poe chose to set it in a different way because the lines came out long, but it's just a ballad. Poe is just taking a certain kind of beautiful stroll (165).

The demonstration focuses intensely on the sensual nature of poetry rather than on an abstracted form of aestheticism. Poetry is a game and rules matter very much to the narrator, as his preference of rhyme over free verse and his obsession with rhythm show, but rhymes should not be considered as artificial exercises in style. They are deeply connected with the way human beings apprehend language, the narrator argues in Chapter Seven, proving their natural origins. His recurrent injunctions to "listen" or to "look" testify to his desire to breathe life into poetry and revitalize the abstracting forms of criticism, or, as his editor puts it in the catalog copy of his unfinished anthology, "Chowder [...] reawakens our sense of the fructifying limitlessness of traditional forms" (44).

The rejection of normative and deadening rules is matched by a loose but extremely dynamic handling of structure and style. Chowder's theories on iambic pentameter rely on the use of oralized form and structure rather than the rigorous framework of Artes 
Poeticae. Commenting on canonical opuses of written poetry, the narrator scatters his discourse with spontaneous and loose connections such as "anyway," "basically," "Oki dokey?" The basic rules of rhetoric and syntax that recommend avoiding repetition are ignored: "I am basically willing to do anything. I am basically willing to do anything to come up with a really good poem" (3). This looks like thought progressing on the page, as "truth opening its petals" to borrow a Chowderian image (3). An abnormally frequent use of dashes marking a break or hesitation inscribes Paul's thoughts within the framework of perceptible time, namely the time it takes to think and to write, or what Genette calls the "narrative time" (228-34). Purely self-conscious in style, this novel overtly shows how it was written. Writing takes the tangible form of an ongoing activity. The abundance of figures of self-correction, such as epanorthosis, shows that truth is being constantly tested and that nothing is fixed immutably. Corrections may stem from a quest for exactness: "For instance: here's a recent New Yorker. Actually, no -it was published almost six years ago" (20); or they may concern the very issue at stake, that is, a definition of poetry: "Poetry is prose in slow motion. Now, that isn't true of rhymed poems" (1). Immediacy of transmission is brought to the fore at the expense of the rigidity of immutable knowledge.

This emphasis on immediacy and oralization cannot be dissociated from the vocal and sonorous quality of language the narrative displays. On a thematic level first, the narrator confides his obsession about the spoken word when it comes to poetry. Poetry should not be internalized but proclaimed or sung. This notion also accounts for all the musical scores scattered throughout the narrative, which represent the narrator's own humming and personal interpretation of the lines, as in the example below where the narrator has composed a tune for a poem by Walter Scott:

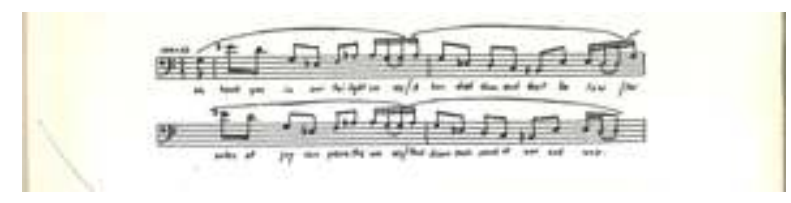

(3)

In the following example, two lines taken from a poem by $19^{\text {th }}$-century poet Alice Carey have been set to music so that the reader slows down and "begin[s] to hear the wisdom in what she's saying" (154):

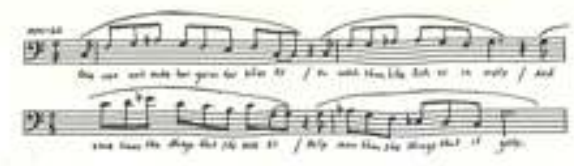

(155)

On a stylistic level, it is the oralization of printed words, as noted above, and their vocalization that help dynamize the narrator's theories on rhyme and rhythm. To maintain the illusion of speech and sound, the narration relies on an exuberant use of onomatopoeia. The parasites of an old BBC radio record of Tennyson are transcribed onto the page through multiple series of consonants: "pkkkfffffffrrrfffff-fff"! pkkkffffffrrrffff-fff [...]" (151). Another series of letters serves to transcribe the muffled sound made by page-turning: "He turns the page, and you hear the schwoooeeeet, and you want to cry" (30). Humming ("dum deem, deedledeel, deedledeem" [155]) and sonorous exclamations ("Haaaaahhhh! [196]) also find their way onto the page, while 
murmurs materialize in smaller characters: "Then sometimes you want to whisper it, like this: "give me my scallop-shell of quiet." (62). The narrator also makes extensive use of vocative expressions ("But at least she [Alice Quinn] actually accepted some of my own poems. Thank you, Alice!" 21). Additionally, the narrator transforms mute typographical marks into audible words, for example the words "quote" and "unquote" are sometimes copied out, and therefore read as if issued from an actual voice (14). These devices enhance the auditory quality of Paul's logorrhea. But as noted earlier, Paul's journal is not playing solo, for it is interlaced with many other voices. Dialogues and exchanges, real or imaginary, abound. The voice of the departed Roz resonates throughout the chapters in mnemonic interludes ("Roz said but Sweetie, you're spending all this money and we don't have it" [30]). Chirping birds keep interrupting the demonstration's progress $(62-63)^{8}$ while here and there a noisy little mouse pops into Paul's kitchen and his manuscript (62-63). Interactions with neighbors, friends, dates and overheard conversations at the store are most of the time reported as direct speech in the narrative. Sound and "the proclaimed word," the festive marketplace and the "cries of Paris" are prominent features of carnival culture, Bakhtin showed in his analysis of Rabelais' world (218). From his solitary plastic chair up in the barn, the anthologist voices boisterous addresses to a variety of individuals-editors, living or dead poets, carpenters, neighbors and passers-by, which generates a lively atmosphere that is part of the carnivalizing spirit of this novel.

Another carnivalesque feature that distances the narrator's critical discourse from the established genre is the extravagant number of references to eating. Hardly a page goes by without an allusion to food, if only as metaphors, similes and puns. This aspect may be linked to the sensuous drive that also governs Paul's life. For Chowder, as his name would have it, ${ }^{9}$ is a bon vivant. The use of food imagery, which takes various forms, gives concrete and physical substance to Paul's discourse and reminds the readers that artistic creation is dependent on bodily function. The answer to the question "Why is rhyme so important to speech?" is considerably delayed by a detailed description of the chicken plate Chowder's neighbor brings him as he sits pondering the issue (105). Food whimsically worms its way into every bit of his narrative, as for example in this passage on the overrated importance of iambic pentameter: "People are going to feed you all kinds of oyster crackers about iambic pentameter. They're going to say, oh ho ho, iambic pentameter! The centrality of the five-stress line! Because 'pent' is five in Babylonian, and five [...] is the number of slices of American cheese you can eat in one sitting" (10). As Bakhtin argues, "the encounter of man with the world, which takes place inside the open, biting, rending, chewing mouth, is one of the most ancient and most important objects of human thought and imagery. Here man tastes the world, introduces it in its body, makes it part of itself' (229). Baker's over-emphasis on food imagery in this poetry anthology testifies to his overpowering desire to celebrate life. Sounds and eating references all point to a joyful feast of communication and exchange with the world.

"How do you achieve the presence of mind to initiate the writing of a poem?" (236). The final twist to this story of writer's block comes as the anthologist is asked by a "real" person at a conference on "the meters of love" to explain the very origins of poetrymaking. The poet suddenly forgets all about the rules of scansion, his own new rules included, and delivers a "secret" that shows poetry and life as intricately connected: 
"I'll tell you how. I ask a simple question. What was the very best moment of your day?" What follows is an uninterrupted writing marathon in which the narrator composes twenty-three poems and completes a "clean draft" of the introduction (241). This outpouring does not happen on the second floor of a remote and isolated barn or ivory tower but "on the kitchen table" (241). As the writing proceeds, the poet swaps his mental representation of a competitive poetry ladder to Parnassus for "an aluminum ladder for real" with which he will help his neighbor build a house (242). The last pages see the narrator return to Roz, to social life, and to "badmintonage" (243). This return to "real life" was only made possible by the creative resources of play, and in this case, by the game of fiction played by Chowder, itself mirroring the elaborate game played by Nicholson Baker. "You need the art in order to love the life," the narrator had declared earlier (190), which aptly illustrates the process Nicholson Baker describes in this metafictional novel. Baker's novel, Linda Hutcheon would argue, "is not a copy of the empirical world, nor does it stand in opposition to it. It is rather a continuation of that ordering, fiction-making process that is part of our normal coming to terms with experience" (Hutcheon, 89). In that respect, The Anthologist provides a good response to Jean-Marie Schaeffer's question in Pourquoi la fiction? The Anthologist can even be considered as a fictional counterpart to Shaeffer's critical theories: reflecting as it does on the mechanics of writing while playing a game of make-believe, Baker's novel provides a dynamic illustration of the creative possibilities offered by that human impulse towards fiction or "ludic feint" as Schaeffer calls it (11, passim). Indeed, what the narrator claims he has achieved at the end of the novel-"a two-hundred and thirty page" introduction, "a clean draft" that "explains things but clumsily"-strangely resembles the two-hundred-and-forty page book the reader is holding. Through the freedom generated by play and the make-believe dynamics of his discourse, Chowder's writings have become a speculative metaphor for the preface that could not be written.

"Another story about a writer writing a story! Another regressus in infinitum!" a character famously complained in "Life-Story," one of John Barth's short stories (117). "Who doesn't prefer art that at least overtly imitates something other than its own processes?" he pursued (117). Baker shows that he does not, since it is this overt meditation on the mechanics of writing that gives birth to The Anthologist. "There is much freedom-inducing potential in metafiction generally, not when seen as a degenerate version of a moribund genre, but when recognized as a significant 'vital' mimetic form of literature" (161-62), Linda Hutcheon concludes at the end of Narcissistic Narrative: The Metafictional Paradox. This a view that applies not only to the narrator's endeavours to reinvent the rules of preface-writing but also to Baker's own endeavours with metafiction. More than three decades after Hutcheon offered a typology of the genre, writing metafiction has become quite a challenge, even for the author of The Mezzanine. While representing Chowder's frantic quest for a new voice that would refresh our perception of poetry, Baker seems to be himself commenting on the challenges implied in writing novels in the $21^{\text {st }}$ century. But turning the preface that the narrator was unable to write into a novel that in its turn offers a playful meditation on the mechanics of writing, Baker has given birth to a form of ludic metametafiction, and proved that in the early $21^{\text {st }}$ century, it is still possible to give a new twist to that now well-established literary genre. 


\section{BIBLIOGRAPHIE}

Works Cited

BAKHTIN, Mikhaill, The Bakhtin Reader, selected writings of Bakhtin, Medvedev and Volohinov, London, E. Arnold, 1994.

---, Problems of Dostoievski's poetics, University of Minnesota Press, 1984.

BAKER, Nicholson, The Anthologist, New York, Simon \& Schuster, 2009.

---, U and I, New York, Random House, Vintage Books, 1991.

BARTH, John, Lost in the Funhouse, New York, Doubleday, 1968.

BEAUjour, Michel, “The Games of Poetics," Yale French Studies, 41, 1968, 58-67.

CAILLOIS, Roger, Man, Play and games [1958], Translated from the French by Meyer Barash, New

York, Free Press, 1961.

Carroll, Lewis, Alice in Wonderland [1865], New York, Norton Critical Edition, 1992.

FINK, Eugene, "The Oasis of Happiness: Toward an Ontology of Play," transl. Ute Saine and Thomas Saine, Yale French Studies 41,1968, 19-30.

GENETTE, Gérard, Figures III, Paris, Gallimard, 1972.

HUIZINGA, Johan, Homo Ludens, a Study of the Play Element in Culture, Boston, Beacon Press, 1950.

HUTCHEON, Linda, Narcissistic Narrative, The Metafictional Paradox, New York, Routledge, 1984.

NАВоKоV, Vladimir, Pale Fire, New York, Vintage International, 1989.

SCHAEFFER, Jean-Marie, Pourquoi la Fiction ?, Paris, Editions du Seuil, 1999.

SCHILLER, Friedrich, On The Aesthetic Education of Man in a Series of Letters. Trans. E.M. Wilkinson and L.A. Willoughby. Oxford: Clarendon Press, 1967.

WAUGH, Patricia, The Theory and Practice of Self-Conscious Fiction, London, Routledge, 1984.

RAWDON WILSON R., Explorations in Play, Game and Narrative Theory. Northeastern University Press, Boston, 1990.

\section{NOTES}

1. As this article was being submitted for publication, Baker published The Traveling Sprinkler, a novel that works as a sort of sequel to The Anthologist (Blue Rider Press, 2013). In this novel, Paul Chowder returns, focusing this time on songs and music.

2. The notion, already part of Huizinga's analysis in 1930, was made famous by R. Caillois' typology of plays in Man, Play and Games (translated from the French Des Jeux et des Hommes, 1958). 3. Johan Huizinga defines play as "a free activity standing quite consciously outside 'ordinary life' as being 'not serious', but at the same time absorbing the player intensely and utterly" (13).

4. If Chowder fails to entertain his neighbors with his embarrassing ukulele solo and social selfconsciousness, on the other hand, it is precisely his self-consciousness as a narrator that turns the episode into a humorous novelistic scene. 
5. Referring to Kinbote's role in Nabokov's Pale Fire, Tony Tanner observed that "On lexical playfields, a man can be a king, even if he is a king in hiding," while Gradus, who represents in the novel everything that is hostile to art and imagination is doomed forever to get lost as he approaches the city of Lex (Tanner, 38).

6. See Linda Hutcheon's analysis of what she has labelled "historiographic metafiction" (5).

7. For a detailed analysis of the intricate relationship between Bakhtin's concept of carnivalization and literary play, see R. Rawdon Wilson's analysis on "The Play of Carnival and the Carnival of Play", in In Palamedes' Shadow, Explorations in Play, Game \& Narrative Theory (25-73).

8. Another allusion to Nabokov's Pale Fire. Kinbote's Foreword to his edition of Shade's poem is interrupted from the start by narratorial intrusions, as for example a passage on "those amusing birds," or another one on the "very loud" noise coming from "the amusement park in front of [his] present lodgings" (9).

9. A feature that "Baker" shares with him.

\section{RÉSUMÉS}

L'article suivant propose d'explorer les fonctions du jeu littéraire dans le huitième roman de Nicholson Baker, The Anthologist, récit de métafiction mettant en scène un narrateur écrivain et poète qui, tentant de rédiger l'introduction d'une anthologie de poésie, est confronté à la page blanche.

Alors que c'est la nature compétitive (agôn) de la création littéraire qui dans un premier temps coupe court au plaisir de la création, comme le montrera la première partie de l'analyse, c'est grâce aux vertus du jeu éducatif (paideia) et la création d'un monde alternatif que la créativité du narrateur se libère et produit les pages qui constituent ce livre. Se penchant sur le rôle de la liberté comme concept fondamental de la création de cet Ars Poetica contemporain, un troisième moment de l'étude met au jour la carnavalisation du langage et des formes comme manifestation riche et féconde du jeu littéraire.

The following article focuses on the function of literary play in Nicholson Baker's The Anthologist, a meta-fictional novel whose narrator Paul Chowder is a writer and poet who struggles to write the introduction of a forthcoming anthology of rhymed poetry. Whereas it is the competitive nature (agon) of literary creation that initially suspends the pleasure of creation, as will be reviewed in the first part of the analysis, it is through the virtues of educational play (paideia) and the creation of an alternative world that narrative creativity is released and produces the pages that constitute this book. Focusing on freedom as a pivotal concept in the creation of this contemporary Ars Poetica, the analysis then reviews the carnivalization of language and forms as a resourceful manifestation of literary play.

\section{INDEX}

Mots-clés : Nicholson Baker, jeu littéraire, métafiction, écriture réflexive, Bakhtine, carnaval et carnavalisation, dialogisme, agôn, compétition, réalité alternative, paideia, jeux de rôles

Keywords : Nicholson Baker, Literary play, metafiction, self-conscious writing, Bakhtin, carnival and carnivalization, dialogism, agon, competition, alternative reality, paideia, role-playing 
AUTEUR

YANNICKE CHUPIN

Université Cergy-Pontoise 